\title{
PROCESSO JUDICIAL, TRIBUTAÇÃO E CONCORRÊNCIA: A COISA JULGADA E SUA RESCISÃO NO NOVO CPC
}

Rogerio Moluica

Mestre e Doutor em Direito Processual pela Universidade de São Paulo, Pós-Doutorando pela Universidade de Marília.

Jonathan Barros Vita

Mestre e Doutor em Direito Tributário pela Pontifícia Universidade Católica de São Paulo, Docente e Coordenador do Programa de Mestrado da Universidade de Marília.

\section{Resumo}

A maior ênfase aos precedentes vinculantes implica criação de modos eficazes de revisão de decisóes que transitaram em julgado antes da pacificação do entendimento pelos Tribunais Superiores. Passado o prazo decadencial de dois anos para o ajuizamento de Ação Rescisória, surgem dúvidas se seria possível a revisão dessas decisóes contrárias, nos termos do previsto no artigo 505, I , do novo Código de Processo Civil (CPC). Alternativamente, o Novo Código de processo Civil buscou resolver o problema ao prever que um novo prazo para o ajuizamento de Ação Rescisória no caso da decisão transitada em julgada for contrária ao entendimento do Supremo Tribunal Federal. A questão se mostra muito atual no âmbito tributário com a edição do Parecer Normativo no 492/2011 da Procuradoria Geral da Fazenda Nacional, que prevê o afastamento automático das decisões transitadas em julgado e que forem contrárias aos paradigmas dos Tribunais Superiores. A revisão da decisão transitada em julgado também pode ser importante para a manutenção da concorrência no mercado, pois se somente uma empresa possuir uma decisáo que a isente do pagamento de determinado imposto, esta empresa terá uma vantagem muito grande frente aos seus concorrentes e acabaria criando um desequilíbrio no mercado.

\section{Palavras-chave}

Coisa Julgada; Tributação; Novo Código de Processo Civil; Direito Concorrencial.

\section{Abstract}

The emphasis on binding legal precedents imposes the creation of efficient ways to review decisions that are res iudicata before the pacification of the jurisprudence by the 
Superior Courts. Being elapsed the term of two years for the rescinding action, there are doubts about the revision of those contrary to the jurisprudence decisions on the terms of article 505, I of the new Code of Civil Procedure (BCCP). Alternatively, the New Code of Civil Procedure aimed to solve the problem, with a new term to fill the Rescissory Action, in the case of res iudicata were contrary to the understanding of the Supreme Court. This problem is very current on the taxation realm with the edition of the Normative Opinion n. 492/2011 of the General Attorneys Office for Fiscal Affairs, which foresees the automatic set aside of the res iudicata that were contrary to the understanding of the Supreme Court. The revision of this res iudicata maybe also important to the maintenance of the competition of a free market, as if only a company possesses a decision that exempts it of the payment of a specific tax, this company will have a great advantage in face of its competitors and this would create disequilibrium in the market.

\section{Key words}

Res Judicata; Taxation; New Code of Civil Procedure; Competition Law.

\section{Introdução}

Contextualizando o problema estudado, tem-se um Novo Código de Processo Civil (Lei 13.105/2015). Um novo ordenamento que foi concebido para tentar dar maior celeridade aos processos. O Novo Código tem como um dos seus alicerces o respeito aos precedentes, pretendendo dar mais segurança e previsibilidade aos litigantes.

Logo, ocorreu uma nítida aproximação do nosso sistema aos dos países que adotam o common law, informados pelo princípio do stare decisis, que prega o respeito aos julgados anteriores, amplificando o princípio constitucional da segurança jurídica.

O núcleo deste estudo, portanto, lida com as aproximaçôes e distanciamentos entre direito processual, direito tributário e direito concorrencial, tendo como objetivos centrais estabelecer um diálogo entre estes subsistemas, além de determinar como os princípios deles podem ser harmonizados/ponderados, evitando que uma decisão judicial tenha impactos permanentes no sistema e prejudique todos os outros participantes.

Estabelecendo o pano de fundo histórico da controvérsia, a Constituição Federal e o Código de Processo Civil vieram sendo modificados no decorrer dos anos para que se pudesse ter um maior respeito aos julgados das Cortes Superiores, com a introdução, por exemplo, da Súmula Vinculante e do julgamento por amostragem dos Recursos Extraordinário e Especial repetitivos. Entretanto, com a aprovação do novo código é que realmente ter-se-á todo um sistema fincado no respeito aos precedentes, apesar do fato que, como será visto, não houve modificação substancial no direito positivo relativo a espécie.

Com um novo ordenamento calcado no julgamento de paradigmas que seráo aplicados a todos os outros processos que versem sobre a mesma tese, e que visam a uniformizar 
os julgamentos, evita-se que se tenham decisóes conflitantes. Entretanto, surge o problema de como se tratar os julgados que por um motivo ou por outro acabam se afastando desse entendimento padronizado e transitam em julgado.

De fato, a eternização de um julgado não convergente com o entendimento atual dos Tribunais Superiores pode gerar graves problemas concorrenciais, afetando os princípios constitucionais da livre concorrência e livre iniciativa, pois somente um dos competidores pode ficar obrigado ao pagamento de um tributo enquanto todos os outros náo estáo ou vice e versa.

Prossegue-se com a investigação de como os instrumentos de relativização da coisa julgada podem ser utilizados para corrigir eventuais distorçóes concorrenciais criadas, tendo especial foco nas açôes rescisórias e no artigo 505, I do novo CPC (reproduçáo fiel do artigo 471 do antigo $\mathrm{CPC}$ ), contrapondo estes institutos às teses do Parecer Normativo no 492/2011 da Procuradoria Geral da Fazenda Nacional, o qual é analisado pormenorizadamente no estudo empreendido.

Na sequencia é feita a análise do Novo Código de Processo Civil e de que forma o novo ordenamento procurou resolver o problema objeto do estudo.

Finalmente, a abordagem deste trabalho parte do método empírico-dialético, utilizando-se da pesquisa bibliográfica e jurisprudencial e será empreendida para lidar com tema de táo grande importância para o sistema jurídico brasileiro, tendo como pano de fundo um sistema de referência que compatibiliza o giro linguístico, representado através do Constructivismo Lógico-Semântico de Barros Carvalho', a Teoria dos Sistemas de Luhmann $^{2}$ e o Law and Economics de Posner ${ }^{3} e^{4}$.

\section{Os Precedentes, a Coisa Julgada e sua Superação pelos Novos Entendi- mentos dos Tribunais Superiores}

\subsection{Novo Ordenamento Processual Brasileiro e o Respeito aos Precedentes Judiciais}

Aparte as grandes mudanças sofridas pelo sistema judicial brasileiro com a EC 45, em 16 de março de 2015 foi sancionado o novo Código de Processo Civil, visando à

1 CARVAlHO, Paulo de Barros. Direito Tributário: linguagem e método. $2^{\text {a }}$ edição. São Paulo: Noeses, 2008.

2 LUHMANN, Niklas. Law as a social system. Oxford: Oxford University Press, 2004.

3 Para um apanhado geral sobre Law and Economics: ROEMER, Andrés. Derecho y economía: uma revisión de la literatura. Cidade do México: ITAM, 2000.

4 Já na doutrina brasileira, como autores que trabalham com este sistema de referência, mais especificamente voltado ao direito (tributário) brasileiro, entre outros: CARVALHO, Cristiano Rosa de. Teoria do sistema jurídico: direito, economia, tributação. São Paulo: Ed. Quartier Latin, 2005; CALIENDO, Paulo. Direito tributário e análise econômica do direito: uma visáo crítica. Rio de Janeiro: Elsevier, 2009; e SCHOUERI, Luís Eduardo. Direito Tributário. São Paulo: Saraiva, 2011. 
obtenção de um processo mais célere e efetivo. Para tanto, o novo ordenamento prevê o respeito aos precedentes, isto é, afastou-se um dos pilares do nosso processo civil, que seria o livre convencimento do juiz para decidir as causa. Com a entrada em vigor do novo código, os juízes deverão respeitar o entendimento dos Tribunais Superiores e não serão mais livres para decidir a causa segundo o seu livre convencimento.

Parece fazer sentido tal previsão, pois se o juiz decide de forma contrária ao entendimento pacificado dos tribunais superiores, a parte tem de percorrer um longo e penoso caminho para tentar reverter tal decisão nos Tribunais Superiores.

Dadas todas as dificuldades no manejo dos Recursos Extraordinário e Especial ${ }^{5}$ e de todas as armadilhas que são impostas aos recorrentes pela jurisprudência defensiva dos tribunais superiores, é muito comum que se tenham decisóes transitando em julgado com entendimentos completamente díspares dos pacificados nos Tribunais Superiores.

Deste modo, a necessidade de que os juízes apliquem os entendimentos consolidados dos Tribunais Superiores, trará maior segurança e previsibilidade aos processos.

\subsection{A Coisa Julgada e os Novos Entendimentos dos Tribunais Superiores}

A Coisa julgada é um princípio norteador do Estado Democrático de Direito e está inserida no artigo $5^{\circ}$ da Constituiçáo Federal, precisamente em seu inciso XXXVI, que dispõe que: "A lei não prejudicará o direito adquirido, o ato jurídico perfeito e a coisa julgada"6.

5 Para o Secretário da Segurança Pública do Estado de São Paulo, Alexandre de Moraes, "Não é possível, nem razoável, que o ordenamento jurídico possa conviver com decisōes absolutamente díspares na interpretação da Constituição ou de lei. (...) Criticar a questão de uma única interpretação da lei, de súmula vinculante ou de efeitos vinculantes na jurisdição constitucional, dizer que isso vai ferir a independência dos juízes, é algo que não existe no resto do mundo; não é uma crítica séria pois o juiz tem total independência para julgar todos os fatos, todas as provas, é ele quem vai dizer qual lei se aplica. Porém, quando ele diz" se aplica esse artigo da Constituição" ou "se aplica esse artigo da legislaçáo", tal lei só pode ter uma interpretação. A Constituição não pode valer de uma forma para uns, de outra forma para outros, e isso ela própria já prevê. Como se pode dizer que isso garante a segurança jurídica e o princípio da igualdade? Ah, mas vai até o STJ, e depois vai fixar um único posicionamento". Só $2 \%$ dos casos chegam ao STJ, seja pela falta de acesso à Justiça, seja porque não há pré-questionamento, mas não se chega aos Tribunais Superiores. Entáo, onde está o princípio da igualdade? Se você tem um advogado melhor, você chega, se você não tem, você não chega, só que a lei deve ter uma única interpretação." (MORAES, Alexandre de. "O Papel das Cortes Superiores. Harmonização do Direito na Globalização", in Encontro Brasil - Espanha: A Reforma Processual, coord. Cláudio Lembo, São Paulo, Minha Editora, Brasília, Instituto Tancredo Neves, 2006, p. 73/74).

6 Segundo Nelson Nery Júnior: "Sua proteçâo não está apenas na CF, art. 5\%, XXXVI, mas principalmente na norma que descreve os fundamentos da república (CF, art. 1\%). O Estado Democrático de Direito (CF, art. $1^{\circ}$, caput) e um de seus elementos de existência (e, simultaneamente, garantia fundamental - CF, art. $5^{\circ}, \mathrm{XXXVI)}$, que é a coisa julgada, são cláusulas pétreas em nosso sistema constitucional, cláusulas essas que não podem ser abolidas nem por emenda constitucional (CF, art. 60 , $\$ 4^{\circ}$, I e IV), porquanto 
A confrontação entre a decisão transitada em julgado e a posterior edição de precedente em sentido contrário vem sendo muito verificada no âmbito do Direito Tributário. É muito comum um Contribuinte conseguir uma decisão transitada em julgado o desonerando do pagamento de um tributo e futuramente os Tribunais Superiores pacificarem o entendimento de que tal tributo seria devido.

Dificuldade maior surge se a pacificação no entendimento somente ocorreu após decorrido o prazo para o ajuizamento de Ação Rescisória. Neste caso o sistema poderá prestigiar a segurança ao estabelecer que a decisão não pode ser alterada, mesmo no caso de ser contrária ao entendimento recém pacificado pelos Tribunais Superiores. Por outro lado, o sistema pode privilegiar a isonomia e a uniformidade na aplicaçáo do precedente, prevendo que ele deve ser aplicado a todos os casos, independentemente da existência do trânsito em julgado, a partir da sua edição.

De outro lado, um distinto dispositivo legal possibilitaria a revisão das decisóes transitadas em julgado que possuam efeitos continuativos ou que abarquem relaçóes que se repetem no tempo, este seria o artigo 471, I, do antigo Código de Processo Civil ${ }^{7}$, o qual foi meramente reiterado no novo CPC em seu artigo $505 .^{8}$

De fato, tal dispositivo prevê que nos casos de relação jurídica continuativa, como normalmente ocorre nos casos tributários, o juiz só poderá decidir questôes já anteriormente decididas se ocorrer uma modificação no estado de fato ou de direito.

Portanto, para os defensores da revisão das decisões transitadas em julgado, a consolidação do entendimento do Tribunal Superior em sentido contrário geraria uma modificação no estado de fato ou de direito, possibilitando a revisão da decisão transitada em julgado.

bases fundamentais da República Federativa do Brasil. Por consequência e com muito maior razão, não podem ser modificadas ou abolidas por lei ordinária ou por decisão judicial posterior." (NERY JÚNIOR, Nelson. Teoria Geral dos Recursos. São Paulo: RT, 2004 , p. 511). Já para Humberto Theodoro Júnior e Juliana Cordeiro de Faria: "A Constituição Federal de 1988, ao contrário da Portuguesa, não se preocupou em dispensar tratamento constitucional ao instituto da coisa julgada em si. Muito menos quanto aos aspectos envolvendo a sua inconstitucionalidade. Apenas alude à coisa julgada em seu art. $5^{\circ}, \mathrm{XXXVI}$, quando elenca entre as garantias fundamentais a de que estaria ela imune aos efeitos da lei nova." (THEODORO JÚNIOR, Humberto; e FARIA, Juliana Cordeiro. "O tormentoso problema da inconstitucionalidade da sentença passada em julgado", in Relativização da coisa julgada, Fredie Didier Júnior org, Salvador, Jus Podivm, 2006, p. 167).

7 Art. 471 - Nenhum juiz decidirá novamente as questōes já decididas, relativas à mesma lide, salvo:

I - se, tratando-se de relaçáo jurídica continuativa, sobreveio modificaçáo no estado de fato ou de direito; caso em que poderá a parte pedir a revisấo do que foi estatuído na sentença.

II - nos demais casos prescritos em lei.

8 Art. 505. Nenhum juiz decidirá novamente as questôes já decididas relativas à mesma lide, salvo: I - se, tratando-se de relação jurídica de trato continuado, sobreveio modificação no estado de fato ou de direito, caso em que poderá a parte pedir a revisão do que foi estatuído na sentença;

II - nos demais casos prescritos em lei. 
Igualmente, sempre que se fala em relaçôes jurídicas continuativas, se evoca a Súmula no 239 do Supremo Tribunal Federal que prevê que "Decisão que declara indevida a cobrança do imposto em determinado exercício não faz coisa julgada em relação aos posteriores"?

Parece claro que caso se esteja diante uma sentença declaratória que julgue inconstitucional um tributo e não ocorrendo qualquer alteração fática ou jurídica, essa sentença não pode ser restrita somente ao ano em que a ação foi ajuizada. ${ }^{10}$

De outra parte, os defensores da manutenção da decisão anteriormente proferida lembram que em nosso ordenamento atual a coisa julgada é um instituto dos mais respeitados e só pode ser afastado por meio do ajuizamento de Ação Rescisória, dentro do prazo decadencial de até dois anos após o trânsito em julgado. Os requisitos para o seu ajuizamento são bastante rígidos, já que a rescisão de um julgado transitado em julgado é uma exceção e deve ser evitada.

Para fazer frente a casos mais teratológicos, a doutrina e a jurisprudência acabaram por criar a figura da relativização da coisa julgada, que surgiu inicialmente para afastar injustiças em casos de reconhecimento paternidade, nos quais modernos exames inexistentes à época do trânsito em julgado atestavam resultados diferentes dos que os obtidos nos autos. Posteriormente, a relativização passou a ser utilizada para impedir indenizaçóes em desapropriaçốes fraudulentas e aos poucos em muitos outros casos.

Segundo o Professor Cândido Rangel Dinamarco "não é legítimo eternizar injustiças a pretexto de evitar a eternização de incertezas." ${ }^{11}$ Prossegue o Mestre afirmando que "Não é lícito entrincheirar-se comodamente detrás da barreira da coisa julgada e, em nome

9 A Súmula no 239 do E. Supremo Tribunal Federal recebe muitas críticas de nossa doutrina. O insigne Professor Humberto Theodoro Júnior, em abono à sua conclusão, mostra que o próprio STF, no julgamento do ERE 83.225 (RTJ 92/707), concluiu por uma interpretaçấo menos rigorosa da referida súmula e que "também se afastou sua aplicação às decisôes de mandado de segurança (RE 100.126, Rel. Min. Francisco Rezek, RTJ 108/406)." Por fim, o Mestre encerra o seu texto com a seguinte conclusão: "Se o contribuinte obtém, em mandado de segurança, a declaração de achar-se livre da exigência fiscal de recolhimento de determinado tributo, no exercício de sua atividade mercantil, por ser inconstitucional a lei que o instituiu, a força da coisa julgada se manifestará não apenas no exercício fiscal em que a respectiva sentença foi dada. Perdurará, indefinidamente, em todos os exercícios subsequentes enquanto não for rescindido o julgado, ou enquanto não se alterar o quadro legal normativo a respeito da obrigaçáo tributária alcançada pela declaração contida na sentença (CPC, art. 471, I).” (THEODORO JÚNIOR, Humberto. "Coisa Julgada. Mandado se Segurança. Relação Jurídica Continuativa. Contribuição Social. Súmula no 239 do STF”, in Coisa Julgada Tributária, coord. Ives Gandra da Silva Martins, Marcelo Magalhães Peixoto, André Elali, São Paulo, MP Editora, 2005, p. 179/180 e 185).

10 Esse também é o entendimento de Priscilla Faricelli de Mendonça: "Assim, a despeito do teor da Súmula 239 do STF, conclui-se que em se tratando de decisão de cunho declaratório, a coisa julgada tributária poderá ser estendida a exercícios fiscais posteriores." (MENDONÇA, Priscila Faricelli. "Coisa julgada Tributária”, in Revista Tributária e de Finanças Públicas, n. 98, São Paulo, Revista dos Tribunais, 2011, p. 258).

11 DiNAMARCO, Cândido Rangel. A nova Era do Processo Civil, São Paulo, Malheiros, 2003, p. 227. 
desta, sistematicamente assegurar a eternização de injustiças ${ }^{12}$, absurdos, de fraudes ou de inconstitucionalidades"13.

O problema quanto à revisão das sentenças transitadas em julgado não é um problema apenas de nosso país. Neste sentido, transcreve-se a preocupação do Professor Argentino Roberto Omar Berizonce:

"De todos modos, hemos de convenir que ha devenido indispensable revisar el sistema de protección a la estabilidad de la cosa juzgada, para adecuarlo a las exigencias de un presente donde arrecian los reclamos de justicia intrinseca en concreto, respeto a la verdad jurídica objetiva, efectividad de la justicia y otros similares." 14

Mais especificamente, no campo tributário, a discussão sobre a manutenção da coisa julgada ou a sua revisão se encontrava mais no plano acadêmico, até que em 2011 a Procuradoria Geral da Fazenda Nacional editou o Parecer Normativo no $492^{15}$, que sustenta

12 Nesse mesmo sentido é o entendimento de Evandro Silva Barros "Tais circunstâncias conduzem o exegeta a indagar de que adianta canonizar o instituto da coisa julgada se a paz social se encontra fragilizada, a cada vez que os efeitos do julgado de renovam, principalmente se a imodificabilidade da decisão interessa apenas ao autor da ação, em detrimento de toda a sociedade, se é exatamente esta quem financia o custeio daquele entendimento tido como inquebrável?” (BARROS, Evandro Silva. "Coisa Julgada Inconstitucional e limitação temporal para a propositura da Ação Rescisória”, in Revista de Direito Constitucional e Internacional, n. 47, São Paulo, Revista dos Tribunais, 2004, p. 91).

13 Esse também é o entendimento do Professor Alexandre Câmara, em seu texto Relativização da Coisa Julgada, assim magistralmente coloca a questão: "O direito processual moderno é um sistema orientado à construção de resultados justos. A ideologia do processualista contemporâneo, conhecida como processo civil de resultados, leva á necessária revisấo de diversos conceitos que pareciam firmemente estabelecidos no panteão de dogmas jurídicos. Isto se dá porque não é aceitável que, em um momento histórico como o atual, em que tanto se luta por justiça, possamos abrir mão dela em nome de uma segurança que não dá paz de espírito ao julgado nem tranquilidade à sociedade. É preciso, pois, relativizar a coisa julgada material, como forma de se manifestar crença na possibilidade de se criar um mundo mais justo. O processo só pode ser aceito como meio de acesso a uma ordem jurídica justa. E é preciso crer na possibilidade de construção dessa ordem jurídica justa para que à mesma possa chegar. Afinal, como disse - com a costumeira sabedoria - Calamandrei, "para encontrar a justiça, é necessário ser-lhe fiel. Ela, como todas as divindades, só se manifesta a quem nela crê”. Espero, apenas, que esta exposiçấo seja recebida como uma profissão de fé na justiça e na capacidade que os magistrados brasileiros têm de transformá-la em realidade." (CÂMARA, Alexandre Freitas. "Relativização da coisa julgada", in Relativização da coisa julgada, 2a Ed., Salvador, Jus Podivm 2006, p. 29/30).

14 BERIZONCE. Roberto Omar. "La relatividad de la cosa juzgada y sus nuevos confines", in Processo Civil em Movimento - Diretrizes para o Novo CPC, org. Eduardo Lamy, Pedro manoel Abreu, Pedro Miranda de Oliveira, Florianopólis, Conceito Editorial, 2013, p. 1101.

15 Segundo o Procurador da Fazenda Nacional Adalmo Oliveira dos Santos Júnior: "Ainda náo se sabe como a jurisprudência acolherá o entendimento da PGFN, contudo a preocupação do órgão fazendário não é sem fundamento. Há casos atualmente em que certas sociedades empresárias não pagam determinado tributo em virtude de decisão judicial transitada em julgado, mas a sua concorrente, tem que recolher o tributo sem perspectiva de sucesso em alguma medida judicial, já que houve alteração jurisprudencial e esta não se valeu do entendimento vetusto. Além de uma evidente ofensa ao princípio da livre concorrência, há ainda prejuízo aos cofres públicos." ("Os efeitos da coisa julgada material e a modificação superveniente do direito”, p. 21). 
a cessação da eficácia dos julgados transitados em julgado, nos casos em que a decisão final seja dissociada da posição firmada pelo Supremo Tribunal Federal. ${ }^{16-17}$

$\mathrm{O}$ aludido parecer foi além ao prever que o afastamento da decisão judicial transitada em julgada poderia se dar pelo próprio Fisco, sem a interferência do Poder Judiciário. De fato, o Fisco de posse da decisão paradigma do Supremo Tribunal Federal em sentido contrário à decisão transitada em julgado, passaria de imediato a lançar os tributos que tinham sido afastados pela decisão transitada em julgado. ${ }^{18}$

Logo, já tendo ultrapassado o prazo para o ajuizamento (ou sua impossibilidade dado o entendimento do STF em relação ao caso de mudança de jurisprudência como bem exposto no RE 590809) de Ação Rescisória e caso o Fisco entenda que ocorreram modificaçóes fáticas ou jurídicas aptas a afastar o entendimento transitado em julgado, o melhor caminho seria procurar o Judiciário e somente após a obtenção de

16 Como doutrinador que defende esta posição: VITA, Jonathan Barros. Tributação, direito concorrencial e processo: as mudanças das circunstâncias de fato e de direito no campo da ação revisional do artigo 471 do CPC. In: Paulo Cesar Conrado. (Org.). Processo Tributário Analítico Volume II. 1ed. São Paulo: Noeses, 2013, v. 1, p. 111-138.

17 Como autora que defende a ilegalidade de tal dispositivo: SOUZA, Fernanda Donnabella Camano de. Breves comentários sobre o Parecer PGFN/CRJ no 492/2011 - a coisa julgada em matéria tributária. In: Revista Dialética de Direito Tributário. Sâo Paulo: Dialética, vol. 201, p 70-82, junho 2012; e GONÇALVES, Carla de Lourdes. Coisa julgada: é possível sua alteração em matéria tributária? In: Direito tributário contemporâneo: estudos em homenagem a Geraldo Ataliba. São Paulo: Malheiros, p. 128-137, 2012.

18 Cumpre ressaltar que o Judiciário vem sistematicamente afastando o entendimento previsto no Parecer PGFN no 492 de que a Administração poderia unilateralmente afastar a coisa julgada, conforme se depreende do seguinte julgado do Tribunal Regional Federal da 4a Região:

"PROCESSUAL CIVIL. MANDADO DE SEGURANÇA. COISA JULGADA. TRIBUTÁRIO. PARECER PGFN No 492/11. PREVALÊNCIA DA COISA JULGADA. 1. A sentença de mérito transitada em julgado só pode ser desconstituída mediante ajuizamento de específica ação autônoma de impugnação (ação rescisória) ou outro veículo processual que lhe faça às vezes. 2. Segundo jurisprudência do egrégio STF, a superveniência de decisão do Pretório Excelso, declaratória de inconstitucionalidade de diploma normativo utilizado como fundamento do título judicial questionado, ainda que impregnada de eficácia ex tunc - como sucede, ordinariamente, com os julgamentos proferidos em sede de fiscalização concentrada, não se revela apta, só por si, a desconstituir a autoridade da coisa julgada, que traduz, em nosso sistema jurídico, limite insuperável à força retroativa resultante dos pronunciamentos que emanam, in abstracto, da Suprema Corte. 3. O mesmo entendimento vale para a hipótese em que o STF declara a validade de uma lei, que, precedentemente, foi reconhecida inválida em um processo que, inter partes, transitou em julgado, formando a coisa julgada material favoravelmente ao contribuinte. 4. A tentativa da Administração, por meio do Parecer PGFN no 492/11, de sujeitar a coisa julgada a exame administrativo viola o princípio da separação dos poderes, já que, uma vez regrada a relação jurídica pela normativa individual emitida pelo Poder Judiciário, salvo a superveniência de lei, somente este poderá examinar a conservação e a permanência daquele regramento individual em relação aos fatos futuros. 5. Sentença mantida." (APELREEX 50066184420124047100, OTÁVIO ROBERTO PAMPLONA, TRF4 - SEGUNDA TURMA, D.E. 23/07/2013.) 
uma tutela jurisdicional nesse sentido empreender qualquer cobrança em relação ao contribuinte ${ }^{19-20}$.

Finalmente, não parece correta essa inversão, do Fisco decidir ao seu talante se a decisão judicial transitada em julgada não deve mais prevalecer e obrigar o contribuinte, que está resguardado pelo manto da coisa julgada, a empreender gastos, contratar advogado para resguardar os seus direitos perante o Poder Judiciário.

\section{O Novo Código de Processo Civil e a Relativização da Coisa Julgada Fren- te aos Precedentes Judiciais Contrários}

Aparte o dispositivo do artigo 471 do antigo CPC, este códex previa no artigo 741 que, na execução em face da Fazenda Pública, somente algumas matérias podem ser objeto de Embargos à Execução, dentre as quais se destacava a inexigibilidade do título (inciso II).

O Parágrafo Único do referido dispositivo esclarece que também considera-se inexigível o título judicial fundado em lei ou ato normativo declarados inconstitucionais pelo Supremo Tribunal Federal, ou fundado em aplicação ou interpretação da lei ou ato normativo tidas pelo Supremo Tribunal Federal como incompatíveis com a Constituição Federal, lembrando que tal previsão também ocorre para as execuçôes que não envolvem entes públicos, sendo dispositivo similar disposto no $\$ 1^{\circ}$ do artigo 475 , L do CPC de 1973.

Essa redação do Parágrafo Único do artigo 741 foi basicamente reproduzida pelo $\$$ $5^{\circ}$ do artigo 535 do novo Código de Processo Civil. Entretanto, o novo código esclarece

19 Esse também é o entendimento de Mary Elbe Gomes Queiroz e Antonio Carlos F. de Souza Júnior: "Contudo, o que vem prevalecendo no âmbito dos tribunais, é a necessidade de ajuizamento de ação autônoma para que o Poder Judiciário possa aferir se há ou não causa superveniente que justifique a sustação da eficácia futura da sentença, isto é, a ação material de modificação surge desde a ocorrência do fato modificador, mas a sustação só terá eficácia plena após a certificação dada pelo Poder Judiciário. Isto é, "A Lei Processual não fulmina automaticamente a validade da decisão transitada em julgado nem admite que os órgãos do sistema o façam de ofício, como pretendem os defensores da 'relativização da coisa julgada”. Em qualquer caso, será sempre no âmbito de um novo procedimento que se verificará a efetiva ocorrência da alteração fático-jurídica, constituindo-se essa outra verdade formal que irá embasar uma nova decisão sobre a matéria.” (QUEIROZ, Mary Elbe Gomes. e SOUZA JÚNIOR, Antonio Carlos F. de. "Coisa julgada nas relaçôes tributárias sucessivas e a mudança do estado de direito decorrente do precedente do STF: Limites jurídicos para a aplicação no âmbito do CARF”, in Segurança jurídica: irretroatividade das decisóes judiciais prejudiciais aos contribuintes, coord. Sacha Calmon Navarro Coêlho, Rio de Janeiro, Forense, 2013, p. 159). Os Autores prosseguem: "A norma jurídica que estabeleceu a necessidade do ajuizamento de ação de modificação não possui o escopo formalista. Sua função é, justamente, garantir a segurança jurídica das relaçôes, conciliando a imperatividade da coisa julgada com a dos seus efeitos futuro por meio de decisão judicial.” (p. 164).

20 Como estudo específico na material tributária: KEMPFER, Marlene. GOMES, Anderson Ricardo. "Coisa Julgada Tributária diante da decisão do STF com efeito Erga Omnes e vinculante”, in Revista de Processo, n. 2014, São Paulo, Revista dos Tribunais, 2012. 
que o controle de constitucionalidade concentrado ou mesmo o difuso ensejariam a oposição de embargos à execução.

Já o $\$ 7^{\circ}$ do mesmo artigo 535 esclarece que a decisão referida no $\$ 5^{\circ}$ deve ter sido proferida antes do trânsito em julgado da decisão exequenda. Como grande inovaçáo tem-se o $\$ 8^{\circ}$ que prevê que se a decisão referida no $\$ 5^{\circ}$ for proferida após o trânsito em julgado da decisão exequenda, caberá ação rescisória, cujo prazo será reaberto e contado do trânsito em julgado da decisão proferida pelo Supremo Tribunal Federal.

Lembra-se que, no caso das execuçôes que não envolvam entes públicos, tais disposiçôes podem ser verificadas nos $₫ 14$ e 15 do artigo 525 .

Portanto, o novo Código veio esclarecer que o controle de constitucionalidade poderia ser concentrado ${ }^{21}$ ou mesmo difuso ${ }^{22}$ e se ocorrer após o trânsito em julgado de uma decisão em sentido contrário, reabriria o prazo para o ajuizamento de ação rescisória (2 anos do trânsito em julgado da decisão do STF ${ }^{23}$.

Obviamente, os julgados do Supremo poderão gerar consequências em muitos processos, inclusive já transitados em julgado, mostra-se conveniente que ele seja do Plenário do STF e não de suas Turmas. ${ }^{24}$.

21 Antes do Novo Código de Processo Civil, José Eduardo Soares de Melo defendia que "A decisão em controle difuso de constitucionalidade, ainda que proferida pelo STF e cuja matéria seja objeto de repercussão geral, não constitui fundamento jurídico suficiente para modificar os efeitos da coisa julgada, diante da falta de previsáo normativa."( MELO. José Eduardo Soares de. "Coisa Julgada Tributária. Modulação. Relativização. Decisão em controle difuso de constitucionalidade e os limites de efeitos”, in Direito Tributário e Constituição Federal: homenagem ao professor Sacha Calmon Navarro Coêlho, coord. Eduardo Maneira e Heleno Taveira Torres, São Paulo, Quartier Latin, 2012, p. 486)

22 Segundo Daniel Amorim Assumpção Neves: "Já tive oportunidade de defender que somente o controle concentrado poderia ser utilizado na alegaçáo de coisa julgada inconstitucional, justamente em razáo dos efeitos da decisão, e, nesse sentido, não fiquei satisfeito com a aprovação do texto final do Novo $\mathrm{CPC}$, aprovado pelo Senado. No entanto, nunca deixei de compreender os argumentos dos que pensam diferente, defensores de uma objetivação do recurso extraordinário. Entendo, entretanto, que, se partirmos efetivamente para a eficácia ultra partes do julgamento desse recurso, ao menos algumas condiçóes deveriam ser impostas. Poder-se-ia exigir, por exemplo, que o julgamento tenha se dado sob o rito dos recursos repetitivos, de forma que se tenha uma participação mais ampla e uma maior discussão sobre o tema constitucional." (NEVES, Daniel Amorim Assumpçáo Neves. Novo Código de Processo Civil - Lei 13.105/2015, Rio de Janeiro: Forense; São Paulo: Método, 2015, p. 319).

23 Mesmo antes da previsão do Novo Código de Processo Civil, alguns Autores já defendiam que o prazo para o ajuizamento da Açáo Rescisória se iniciaria do julgamento do Supremo Tribunal Federal que decidir em definitivo a questáo. Neste sentido é o entendimento de Evandro Silva Barros: "Ademais, a reafirmar a tese de que o prazo decadencial não é absoluto, vale ressaltar que a pretensáo jurídica para a reforma da decisão inconstitucional que tenha transitado em julgado, poderá surgir somente após a prolaçáo de decisão definitiva do Supremo Tribunal Federal, quando já tenha transcorrido o lapso temporal constante do art. 495 do CPC, logo, conclui-se que somente com a publicação da decisão da Excelsa Corte é que o prazo para o exercício do direito à ação rescisória deve ser contado." (BARROS, Evandro Silva. "Coisa Julgada Inconstitucional e limitação temporal para a propositura da Ação Rescisória”, in Revista de Direito Constitucional e Internacional, n. 47, São Paulo, Revista dos Tribunais, 2004, p. 92).

24 Nesse mesmo sentido é o Enunciado no 58 do Fórum Permanente de Processualistas Civis (FPPC) que exige que a decisão seja proferida pelo Plenário do Supremo Tribunal Federal. 
Dessa forma, o Novo Código de Processo Civil procura resolver o problema em estudo $^{25}$. De fato, tal dispositivo resolveria no caso do contribuinte cobrar a devolução de tributo posteriormente tido por constitucional pelo Supremo ou no caso inverso, do Fisco cobrar por tributo que posteriormente foi tido inconstitucional pelo Supremo.

Como nota subsidiária, remanesceria a dúvida quanto ao caso objeto do Parecer PGFN $n^{\circ} 492$, pois nesse caso náo há que se falar em oposição de embargos ou impugnação ao cumprimento de sentença. Após a vigência do Novo Código poderia o Fisco lançar de imediato os valores? Neste caso, seria aplicável o novo prazo para ajuizamento de açáo rescisória ( 2 anos da decisáo do STF que julgou de forma contrária à decisão transitada em julgado)?

Conforme anteriormente defendido, náo cabe o lançamento imediato por parte do Fisco, que deve recorrer ao Judiciário para afastar a decisão transitada em julgado. Uma análise sistemática do novo ordenamento parece ratificar o entendimento de que nesse caso o Fisco teria dois anos após o julgamento do Plenário do Supremo Tribunal Federal para ajuizar a Ação Rescisória. Dessa forma, se antes do novo ordenamento já se defendia a possibilidade de se socorrer do Judiciário para tentar afastar a coisa julgada, que acaba se afastando do entendimento consolidado do Supremo Tribunal Federal, com muito mais razão agora se defende que seria aplicável esse novo prazo inicial para o ajuizamento de Ação Rescisória.

Finalmente, cumpre ressaltar que os referidos dispositivos do Novo CPC só serão aplicáveis às decisôes transitadas em julgado após a entrada em vigor do novo código. De fato, prevê expressamente o artigo 1057: "O disposto no art. 525, $\$ \$ 14$ e 15, e no art. $535, \$ 7^{\circ}$ e $8^{\circ}$, aplica-se às decisóes transitadas em julgado após a entrada em vigor deste Código, e, às decisóes transitadas em julgado anteriormente, aplica-se o disposto no art. 475-L, $\$ 1^{\circ}$, e no art. 741, parágrafo único, da Lei no 5.869, de 11 de janeiro de 1973.

Portanto, por mais que se entenda que o Novo Código de Processo Civil possa ter resolvido o problema ao prever que o prazo para o ajuizamento da Ação Rescisória ${ }^{26}$ só

25 Para Antonio do Passo Cabral: “(...) parece, uma vez mais, a despeito da redação do art. 502 do novo CPC, que avançamos na tendência de superação do paradigma da "imutabilidade"ou "indiscutibilidade" em favor de um sistema de estabilidades processuais mais fluido e dinâmico, adaptável para incorporação dos elementos noviter producta (produzidos posteriormente), noviter reperta (que chegaram ao conhecimento dos litigantes após a formação da coisa julgada) e noviter cognita (que não foram conhecidos e portanto, não compuseram o debate); um sistema em que a continuidade assegura estabilidade sem impedir a mudança de posiçóes estáveis, e quando estar for necessária, que possa acomodar a alteração com compensaçôes que fomentem uma redução do impacto da modificaçáo (regras de transiçáo), suavizando a passagem de um regramento estável a outro. Ademais, admitindo a possibilidade de mudança (ao invés de escondê-la no rótulo da imutabilidade), o sistema é mais sincero, racionável e controlável que o método proposto pelas teses de 'relativização da coisa julgada"'. (CABRAL, Antônio do Passo. Coisa julgada e preclusôes dinâmicas: entre continuidade mudança e transiçáo de posiçóes processuais estáveis, $2^{\mathrm{a}}$ ed. Salvador, Jus Podivm, 2014, p. 1301).

26 Cumpre ressaltar que em recente decisão, o Supremo Tribunal Federal decidiu, sob a égide dos Recursos Repetitivos, que havendo na Corte Constitucional mudança posterior de entendimento anteriormente 
inicia-se após a publicação do acórdão do julgamento do Supremo Tribunal Federal, terse-iam ainda milhares de decisóes que transitaram antes da entrada em vigor do Novo Código de Processo Civil e que teriam de ser analisadas pelo Poder Judiciário para se verificar se poderiam perdurar ou se teriam o seus efeitos cassados após o julgamento da Corte Suprema.

\section{A Eternização de Julgados Divergentes e o Direito Concorrencial}

Primariamente, cabe reiterar o fato que os princípios fundantes da Ordem Econômica receberam um capítulo específico na Constituição Federal, tendo como princípios mais importantes a livre concorrência e livre iniciativa, derivados, de uma isonomia econômica entre agentes.

Obviamente, muitos defendem que a isonomia não deveria ser aplicável ao direito processual $^{27}$, o que gera uma aleatoriedade jurisdicional que é contrária a ideia de segurança jurídica coletivizada e a uma ideia de racionalidade do sistema, recriada através do processo evolutivo do sistema jurídico no esquema darwiniano-luhmaniano. ${ }^{28}$

$\mathrm{Na}$ facticidade jurisprudencial brasileira, vários julgados são produzidos no campo da variedade do sistema, sem passar pelos filtros de redundância e seleção, necessários a (re)estabilização do sistema jurídico.

Portanto, cabe determinar a forma de cessação dos efeitos de julgados que se afastam do entendimento consolidado dos Tribunais Superiores, o que também visa à manutenção da concorrência no mercado, pois se somente uma empresa possuísse uma decisão que a isentasse do pagamento de determinado imposto, esta empresa teria uma vantagem muito grande frente aos seus concorrentes e acabaria criando um desequilíbrio no mercado, afetando a livre concorrência.

Igualmente, caso todas as empresas de um determinado setor não necessitarem pagar um imposto e somente uma ter de pagar em virtude de uma decisão (contrária) transitada em julgado, tal desequilíbrio seria mantido ${ }^{29}$.

consagrado, não caberia ação rescisória para afastar o antigo entendimento e fazer valer o posterior (STF, Pleno, RE no 590.809/RS, Rel;. Min. Marco Aurélio, j. 22/10/2014). Portanto, a previsão do Novo Código de Processo Civil será uma inovação, já que o novo julgamento do Supremo vai possibilitar o ajuizamento de Ação Rescisória e a publicação do acórdão do referido julgado passa a ser o marco inicial para o cômputo do prazo de dois anos para o ajuizamento da Ação Rescisória.

27 Em sentido de tal aplicação: VITA, Jonathan Barros ; DINIZ, M. L. C. Direito concorrencial e direito tributário: sham litigation em matéria tributária.. Revista Tributária das Américas, v. III, p. 349-370, 2011.

28 LUHMANN, Niklas. Law as a social system. Oxford: Oxford University Press, 2004.

29 Neste sentido é o entendimento de José Carlos Francisco: “Contextualizando a razoabilidade e a proporcionalidade com o confronto entre as decisóes individuais e o entendimento jurisdicional 
Ademais, decisóes judiciais não convergentes com os atuais entendimentos jurisprudenciais podem funcionar como cláusulas artificiais de barreira de ingresso de novos concorrentes no mercado, afetando a livre iniciativa.

Entretanto, isso não quer dizer que se deve inibir o questionamento, por parte dos contribuintes, de exaçóes tributárias que sejam ilegais ou inconstitucionais em tese. A atuação do Poder Judiciário na correção de eventuais desvios legislativos ou normativos relativos à tributação passa por beneficiar (erga omnes) a totalidade dos contribuintes, de forma a evitar que vantagens comparativas individuais oriundas de decisóes judiciais afetem a concorrência ${ }^{30}$.

Obviamente, é possível ter tributaçôes diferenciadas em virtude de decisóes judiciais, como o caso em que uma empresa vai ao Judiciário e consegue afastar a cobrança de um tributo. Já o seu concorrente não ajuíza ação judicial e tem de continuar a pagar o tributo, que o seu concorrente foi exonerado. Nesse caso, é uma opção da empresa em discutir ou não um tributo em juízo. O que se procura evitar é o caso de um concorrente ter uma decisão imutável e que nenhum outro concorrente poderá obter, pois o entendimento dos Tribunais Superiores se consolidou em sentido contrário. Neste caso não se tem uma opção, mas sim uma impossibilidade de se obter a mesma decisão que o concorrente possui.

Com o respeito aos precedentes, tende a diminuir a ocorrência de uma maior homogeneidade nas decisóes judiciais, com menor risco de termos decisóes dispares dos entendimentos consolidados e uma maior segurança jurídica. Portanto, o Judiciário influirá menos no direito concorrencial.

\section{Conclusões}

A partir dos problemas de pesquisa apresentados no decorrer do texto, algumas conclusões podem ser desenhadas:

pacificado (seja ou não com efeito vinculante e eficácia erga omnes), acreditamos que o ordenamento jurídico deve prever meios para a desconstituição da coisa julgada individual desfavorável ao contribuinte para permitir que ele sirva de posiçấo jurisprudencial consolidada no sentido da inexigência do tributo (sob pena de penalizar injustamente aquele que, de maneira legítima, arcou com encargos financeiros e buscou o Judiciário para a solução de lides, pois todos os demais contribuintes estarão se servindo do entendimento jurisdicional pacificado, mesmo aqueles que sequer propuseram a ação judicial ou simplesmente sonegaram o tributo). Do mesmo modo, acreditamos que decisóes isoladas no sentido da inexigência de tributos devam ser desconstituídas, mesmo que transitadas em julgado há anos, para que esses verdadeiros "acidentes judiciais" não criem "paraísos fiscais", em detrimento da igualdade, da segurança geral, da livre iniciativa e da livre concorrência.” In: FRANCISCO, José Carlos. "Igualdade, segurança, livre iniciativa, livre concorrência e relativização da coisa julgada”, in Tributação das Empresas, São Paulo, Quartier Latin, 2006.

30 SILVEIRA, Rodrigo Maito da. "Desequilíbrios concorrenciais decorrentes de decisôes judiciais em matéria tributária”, in Revista Fórum de Direito Tributário, no 59, Belo Horizonte, 2012, p. 172. 
1. O instituto da coisa julgada com o respeito aos precedentes e a manutenção da concorrência nos mercados são compatíveis.

2. De fato, não parece fazer sentido a impossibilidade da revisão de decisões diametralmente contrárias ao atual entendimento dos Tribunais Superiores somente tendo por base a veneração ao dogma da coisa julgada.

3. Tal revisão somente pode ocorrer no âmbito do Poder Judiciário, com a minuciosa análise da decisáo transitada em julgado e do novo paradigma, e náo como pretende a Procuradoria Geral da Fazenda Nacional em seu Parecer Normativo no 492/2011, de forma unilateral por uma das partes.

4. A revisão de entendimentos com modificação de coisa julgada só poderia ocorrer com efeitos ex nunc, como forma de garantir a segurança jurídica da parte que somente cumpria uma ordem judicial e não pode ser penalizada com a retroação da cassação da medida com efeitos retroativos.

5. O novo Código de Processo Civil buscou resolver o problema ao prever um novo prazo para o ajuizamento de Ação Rescisória, dessa vez contado a partir do acórdão do Supremo Tribunal Federal que julgar a matéria de forma contrária à coisa julgada formada em outros autos.

6. Em um mercado globalizado e muito competitivo uma decisão judicial transitada em julgada e que se afasta do entendimento dos Tribunais Superiores pode causar graves desarranjos e criar uma concorrência danosa frente aos outros concorrentes, sendo necessária a busca de um novo equilíbrio no mercado com a revisão dessa decisão judicial, que prejudica a livre concorrência (e iniciativa) no mercado.

\section{Referências}

BARROS, Evandro Silva. "Coisa Julgada Inconstitucional e limitação temporal para a propositura da Ação Rescisória”, in Revista de Direito Constitucional e Internacional, n. 47, São Paulo, Revista dos Tribunais, 2004.

BERIZONCE. Roberto Omar. "La relatividad de la cosa juzgada y sus nuevos confines", in Processo Civil em Movimento - Diretrizes para o Novo CPC, org. Eduardo Lamy, Pedro manoel Abreu, Pedro Miranda de Oliveira, Florianopólis, Conceito Editorial, 2013.

CABRAL, Antônio do Passo. Coisa julgada e preclusóes dinâmicas: entre continuidade mudança e transição de posiçóes processuais estáveis, 2a ed. Salvador, Jus Podivm, 2014.

CALIENDO, Paulo. Direito tributário e análise econômica do direito: uma visão crítica. Rio de Janeiro: Elsevier, 2009. 
CÂMARA, Alexandre Freitas. "Relativização da coisa julgada", in Relativização da coisa julgada, 2a Ed., Salvador, Jus Podivm 2006.

CARVALHO, Cristiano Rosa de. Teoria do sistema jurídico: direito, economia, tributação. São Paulo: Ed. Quartier Latin, 2005.

CARVALHO, Paulo de Barros. Direito Tributário: linguagem e método. 2a edição. São Paulo: Noeses, 2008.

COÊLHO, Sacha Calmon Navarro (org), Segurança Jurídica - irretroatividade das decisôes judiciais prejudiciais aos contribuintes, Rio de Janeiro, Forense, 2013.

DINAMARCO, Cândido Rangel. A nova Era do Processo Civil, São Paulo, Malheiros, 2003.

FRANCISCO, José Carlos. "Igualdade, segurança, livre iniciativa, livre concorrência e relativização da coisa julgada”, in Tributação das Empresas, São Paulo, Quartier Latin, 2006.

GONÇALVES, Carla de Lourdes. Coisa julgada: é possível sua alteração em matéria tributária? In: Direito tributário contemporâneo: estudos em homenagem a Geraldo Ataliba. São Paulo: Malheiros, p. 128-137, 2012.

KEMPFER, Marlene. GOMES, Anderson Ricardo. "Coisa Julgada Tributária diante da decisão do STF com efeito Erga Omnes e vinculante”, in Revista de Processo, n. 2014, São Paulo, Revista dos Tribunais, 2012.

LUHMANN, Niklas. Law as a social system. Oxford: Oxford University Press, 2004.

MELO. José Eduardo Soares de. "Coisa Julgada Tributária. Modulação. Relativização. Decisão em controle difuso de constitucionalidade e os limites de efeitos", in Direito Tributário e Constituição Federal: homenagem ao professor Sacha Calmon Navarro Coêlho, coord. Eduardo Maneira e Heleno Taveira Torres, São Paulo, Quartier Latin, 2012.

MENDONÇA, Priscila Faricelli. "Coisa julgada Tributária”, in Revista Tributária e de Finanças Públicas, n. 98, São Paulo, Revista dos Tribunais, 2011.

MOLLICA, Rogerio. "Parecer da PGFN extrapola e atinge coisa julgada", in Revista Consultor Jurídico de 25/09/2011 - http://www.conjur.com.br/2011-set-25/parecer-492-pgfn-extrapola-atinge-coisa-julgada (Acesso em: 29/09/2014)

MORAES, Alexandre. "O Papel das Cortes Superiores. Harmonização do Direito na Globalização", in Encontro Brasil - Espanha: A Reforma Processual, coord. Cláudio Lembo, São Paulo, Minha Editora, Brasília, Instituto Tancredo Neves, 2006.

NERY JÚNIOR, Nelson. Teoria Geral dos Recursos, 6a ed. São Paulo, Revista dos Tribunais, 2004. 
NEVES, Daniel Amorim Assumpção Neves. Novo Código de Processo Civil - Lei 13.105/2015, Rio de Janeiro: Forense; São Paulo: Método, 2015.

QUEIROZ, Mary Elbe Gomes. e SOUZA JÚNIOR, Antonio Carlos F. de. "Coisa julgada nas relaçóes tributárias sucessivas e a mudança do estado de direito decorrente do precedente do STF: Limites jurídicos para a aplicação no âmbito do CARF”, in Segurança jurídica: irretroatividade das decisóes judiciais prejudiciais aos contribuintes, coord. Sacha Calmon Navarro Coêlho, Rio de Janeiro, Forense, 2013.

ROEMER, Andrés. Derecho y economía: uma revisión de la literatura. Cidade do México: ITAM, 2000.

SCHOUERI, Luís Eduardo. Direito Tributário. São Paulo: Saraiva, 2011.

SILVEIRA, Rodrigo Maito da. "Desequilíbrios concorrenciais decorrentes de decisôes judiciais em matéria tributária”, in Revista Fórum de Direito Tributário, no 59, Belo Horizonte, 2012.

SOUZA, Fernanda Donnabella Camano de. Breves comentários sobre o Parecer PGFN/ CRJ no 492/2011 - a coisa julgada em matéria tributária. In: Revista Dialética de Direito Tributário. São Paulo: Dialética, vol. 201, p 70-82, junho 2012.

THEODORO JÚNIOR, Humberto. “Coisa Julgada. Mandado se Segurança. Relação Jurídica Continuativa. Contribuição Social. Súmula no 239 do STF”, in Coisa Julgada Tributária, coord. Ives Gandra da Silva Martins, Marcelo Magalhães Peixoto, André Elali, São Paulo, MP Editora, 2005.

THEODORO JÚNIOR, Humberto; e FARIA, Juliana Cordeiro. "O tormentoso problema da inconstitucionalidade da sentença passada em julgado", in Relativização da coisa julgada, Fredie Didier Júnior org, Salvador, Jus Podivm, 2006.

VITA, Jonathan Barros ; DINIZ, M. L. C. Direito concorrencial e direito tributário: sham litigation em matéria tributária.. Revista Tributária das Américas, v. III, p. 349-370, 2011.

VITA, Jonathan Barros. Tributaçáo, direito concorrencial e processo: as mudanças das circunstâncias de fato e de direito no campo da ação revisional do artigo 471 do CPC. In: Paulo Cesar Conrado. (Org.). Processo Tributário Analítico Volume II. 1ed. São Paulo: Noeses, 2013, v. 1, p. 111-138. 